\title{
Effect of different conductor tubes on the longitudinal distribution of corn seeds
}

\author{
Dauto P. Carpes ${ }^{1}$, Airton dos S. Alonço ${ }^{1}$, Fernando P. Rossato ${ }^{2}$, \\ André A. Veit ${ }^{2}$, Lucas B. de Souza ${ }^{2} \&$ Tiago R. Francetto ${ }^{3}$ \\ ${ }^{1}$ Universidade Federal de Santa Maria/Programa de Pós-Graduação em Engenharia Agrícola. Santa Maria, RS. E-mail: dautocarpes@gmail.com \\ (Corresponding author); airtonalonco@gmail.com \\ ${ }^{2}$ Universidade Federal de Santa Maria. Santa Maria, RS. E-mail: rossato77@hotmail.com; andreh_veit@hotmail.com; lucassousa758@yahoo.com.br \\ ${ }^{3}$ Universidade Federal de Santa Maria. Cachoeira do Sul, RS. E-mail: tiago.francetto@ufsm.br
}

\section{Key words:}

agricultural mechanization

precision seeding precision agriculture row crop planter seed metering

\begin{abstract}
A B S T R A C T
The correct longitudinal distribution of seeds by the seeder machine is one of the features that most contributes to obtain an adequate plant stand and good crop yield. The objective of this study was to evaluate the longitudinal distribution of corn seeds by seed conductor tube types, combined with a horizontal perforated disc and a pneumatic meter, altering the seeding density rate. The experiment was conducted in a laboratory using a seed meter test bench. Treatments were a combination of two seed meters, six conductor tubes and four peripheral speeds for the meter disc, corresponding to densities of 60, 70, 80 and 90 thousand corn seeds per hectare and were organized in a three-factor scheme with four repetitions. By increasing the seeding rate into the same ground speed, there was a reduction in the percentage of acceptable spacing, this effect being more pronounced when conductor tubes with a small diameter and straight profile were used.
\end{abstract}

\section{Palavras-chave:} mecanização agrícola semeadura de precisão agricultura de precisão mecanismo dosador medição de sementes

\section{Efeito de diferentes tubos condutores na distribuição longitudinal de sementes de milho}

\begin{abstract}
R E S U M O
A correta distribuição longitudinal das sementes pela máquina semeadora é uma das características que mais contribuem para a obtenção de estande adequado de plantas e para a boa produtividade das culturas. Objetivou-se, neste trabalho, avaliar a distribuição longitudinal de sementes de milho por diferentes tipos de tubos condutores, combinados com um dosador de disco alveolado horizontal e um pneumático, variando-se a densidade de semeadura. O experimento foi conduzido em laboratório utilizando uma bancada de ensaio de dosadores de sementes. Os tratamentos consistiram da combinação de dois dosadores, seis tubos condutores e quatro velocidades periféricas do disco dosador, correspondentes às densidades de 60, 70, 80 e 90 mil sementes de milho por hectare e foram organizados em um esquema trifatorial, com quatro repetições. Ao aumentar a densidade de semeadura para uma mesma velocidade de deslocamento, houve redução do percentual de espaçamentos aceitáveis este efeito mais acentuado quando utilizados tubos condutores com pequeno diâmetro e perfil reto.
\end{abstract}




\section{INTRODUCTION}

The seed distribution uniformity in the planting rows is a factor that can contribute in obtaining a suitable stand of plants and therefore a good productivity. Two problems may occur due to non-uniformity in the longitudinal distribution: The appearance of multiple spacing that results in a productivity reduction of intraspecific competition and failure in seeding, that favors the emergence of weeds, which have the tendency to compete with the main crop for light, water, nutrients and $\mathrm{CO}_{2}$ (Pinheiro Neto et al., 2008).

The seeding quality is highly dependent on the metering accuracy performed by the seed metering mechanism, which, according to Dias et al. (2009), is the most important part of the seeder.

According to Kocher et al. (2011), another factor that can affect the uniformity of seed spacing, is the condition of the inner surface of the seed conductor tubes. New ones, with smooth internal walls and with no roughness, lead the seeds in a more evenly and smoother manner, while worn ones can cause delay in the seed fall, changing its arrangement in the row.

Mialhe (2012) states that the vertical conductor, conducting the seeds by the action of gravity, may be highly damaging for precision sowing, causing the rebound effect of the seeds inside the conductor. Jasper et al. (2006) report that the parabolic profile tubes lead the seeds to the furrow more smoothly, reducing this effect.

In this way, the objective of the study was to evaluate, based on the longitudinal distribution of corn seeds, seed conductor tubes of different diameters, their placement in the machine, height from the ground and discharge bend, when combined with two seed meter systems with different forms to discharge the seeds, the horizontal perforated and the vertical pneumatic disc, at different seeding densities and peripheral speeds of the meter disc.

\section{Material ANd Methods}

The experiment was conducted on the premises of the Laboratory of Research and Development of Agricultural Machinery (LASERG), linked to the Federal University of Santa Maria.

A seed meter test bench (BEDOSA) developed by the LASERG staff and a frequency inverter connected to an electric motor was used to change the seed meter disc rotation.

Seeds were placed under a felt-coated conveyor belt, simulating agricultural soil, measuring $17.5 \mathrm{~m}$ of length by $0.15 \mathrm{~m}$ of width. The conveyor belt and the seed metering discs are also activated by a three phase electric motor with asynchronous induction of $2208 \mathrm{~W}$ ( $3 \mathrm{CV}$ ), driven by a CFW08 frequency inverter with single-phase 200-240 V input.

The vertical pneumatic seed meter disc used was the Planting Precision ${ }^{\otimes *}$ model which uses the negative pressure of the air as a means of separation and retention of seeds. Pressure control was achieved through a vacuum gauge, which set the required pressure recommended by the meter manufacturer. A STARA horizontal disc meter was also used.

\footnotetext{
* The mentioning of brands and models do not imply their recommendation by the authors
}

Pionner ${ }^{\circledast} \mathrm{C} 3$ hybrid corn seeds (Zea mays) were used. The main dimensional characteristics of seeds were determined in samples composed of 50 seeds with the aid of a digital caliper, averages of length $10.22 \mathrm{~mm}$, diameter $4.94 \mathrm{~mm}$ and thickness $7.52 \mathrm{~mm}$.

Four seeding densities, 60, 70, 80 and 90 thousand seeds per hectare were used, resulting from four rotations of metering discs at the same displacement speed, simulating a seeding operation of precision agriculture. In Table 1 are shown the settings used in mechanical and pneumatic seed meters.

The conveyor-belt speed was kept at $1.67 \mathrm{~m} \mathrm{~s}^{-1}$ and only the peripheral speeds of the meter discs were altered. The speed used is intermediate to the speeds recommended by ISO $7256 / 1$ standard, which refers to speeds between 1.39 and $1.94 \mathrm{~m} \mathrm{~s}^{-1}$. During the tests, the bench with the discs remained leveled lengthwise and crosswise, and the seeds reservoir was kept at full level.

The manual counting of spacings was performed with the use of a tape-measure extended parallel over the belt. The data were entered into spreadsheets, where they were later classified according to ISO (1984), which divides the spacings into frequency classes, where $\mathrm{X}_{\text {ref }}$ corresponds to the theoretical spacing of each crop and the most commonly used in the spacing divisions described also by ABNT (1994) as: acceptable $\left(0,5 \mathrm{X}_{\text {ref. }}<\mathrm{X}_{\mathrm{i}}<1,5 \mathrm{X}_{\text {ref. }}\right)$, multiple $\left(\mathrm{X}_{\mathrm{i}}<0,5 \mathrm{X}_{\text {ref. }}\right)$ and failure $\left(\mathrm{X}_{\mathrm{i}}\right.$ $>1,5 \mathrm{X}_{\text {ref. }}$ ). The percentage precision obtained by seed meters was calculated by the following Eq. 1 .

$$
\% \mathrm{P}=\left(\frac{\mathrm{SD}}{\mathrm{Xref}}\right) \times 100
$$

where:

$\% \mathrm{P}$ - percentage precision;

SD - standard deviation; and,

Xref - theoretical spacing of each crop.

The observed spacing number was according to the methodology proposed by Dias et al. (2014), of 105 spacing for the corn seeds. The specifications of the conductor tubes used are shown in Figure 1.

The experimental design used was a randomized block in split plots, with $2 \times 6 \times 4$ factorial arrangement with four repetitions, totaling 182 experimental units. The first factor was composed of two seed meter mechanisms, mechanical and pneumatic, the second factor consisted of six conductor tubes, and the third factor, the seeding density rate in four levels.

Table 1. Settings of used seed meters

\begin{tabular}{|c|c|c|c|c|c|}
\hline \multirow{2}{*}{$\begin{array}{l}\text { Frequency } \\
(\mathrm{Hz})\end{array}$} & \multirow{2}{*}{ Seeds $\mathrm{m}^{-1}$} & \multirow{2}{*}{ Seeds ha-1 } & \multirow{2}{*}{$\begin{array}{l}\text { Rotation } \\
\text { (rpm) }\end{array}$} & PS & CBS \\
\hline & & & & \multicolumn{2}{|c|}{$\left(\mathrm{m} \mathrm{s}^{-1}\right)$} \\
\hline \multicolumn{6}{|c|}{ Pneumatic meter } \\
\hline 154.50 & 4.80 & 60.000 & 17.77 & 0.15 & 1.67 \\
\hline 182.45 & 5.60 & 70.000 & 20.74 & 0.18 & 1.67 \\
\hline 210.41 & 6.40 & 80.000 & 23.70 & 0.21 & 1.67 \\
\hline 238.36 & 7.20 & 90.000 & 26.67 & 0.23 & 1.67 \\
\hline \multicolumn{6}{|c|}{ Horizontal disc } \\
\hline 476.50 & 4.80 & 60.000 & 17.14 & 0.17 & 1.67 \\
\hline 558.10 & 5.60 & 70.000 & 20.00 & 0.20 & 1.67 \\
\hline 639.70 & 6.40 & 80.000 & 22.86 & 0.23 & 1.67 \\
\hline 721.40 & 7.20 & 90.000 & 25.71 & 0.26 & 1.67 \\
\hline
\end{tabular}

PS - Peripheral Speed; CBS - Conveyor-belt Speed 


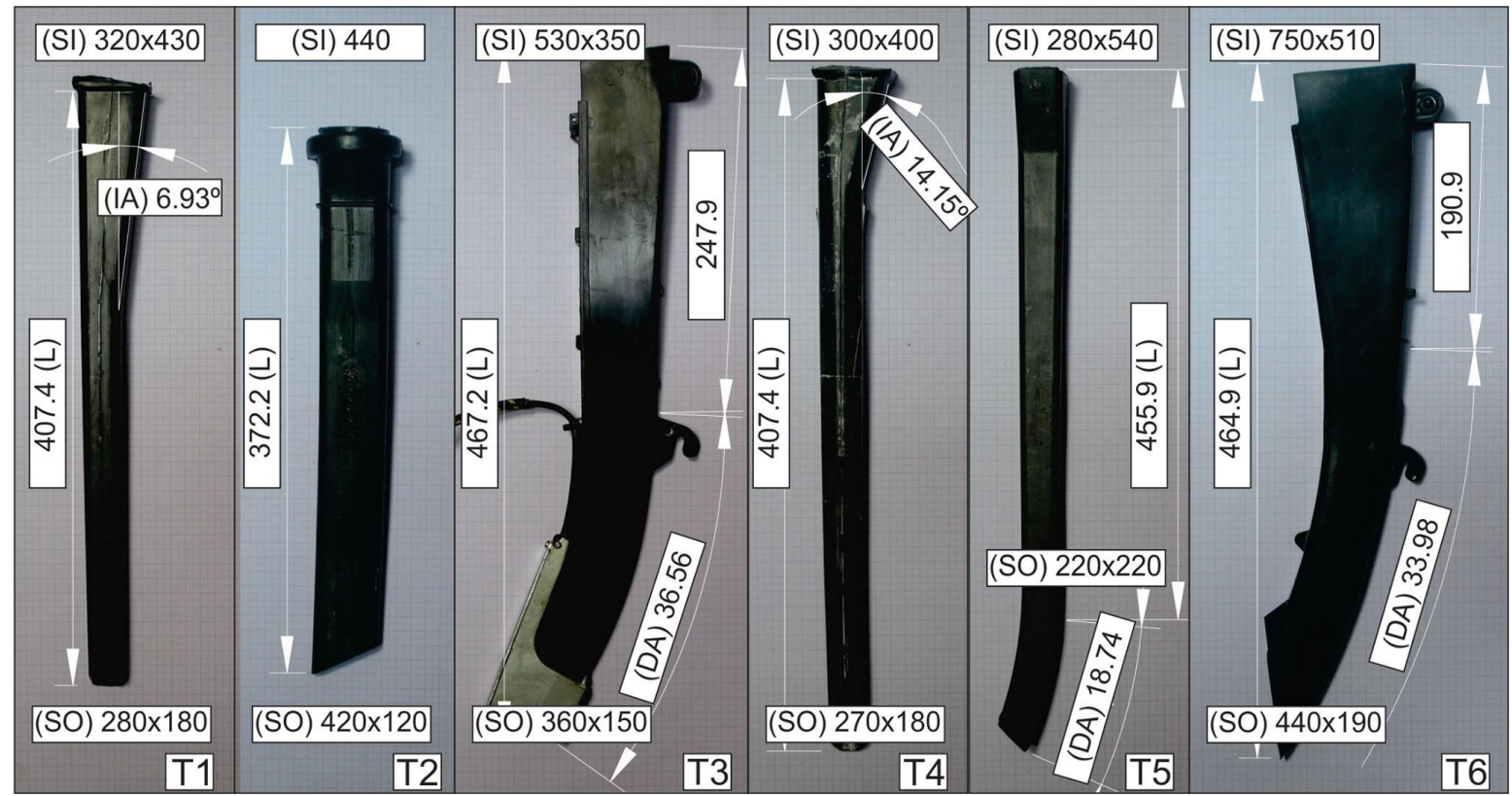

T - Conductor tube; L - Length (mm); IA - Input angle; DA - Discharge angle; SI - Seeds input measures (mm); SO - Seeds output measures (mm)

Figure 1. Dimensional characteristics of seed conductor tubes

The data, were statistically analyzed by using Assistat Software (Silva \& Azevedo, 2016).

The collected average data of spacing between seeds showed normality based on the Kolmorogov-Smirnov normality test and a homogeneity of variances was found when applying the Cochran test. The averages of the data for acceptable, multiple and flawed spacing collected were submitted to variance analysis (ANOVA), when factors significance was found by the F test, the averages were submitted to the Tukey test at $0.05 \%$ error probability to detect differences.

\section{Results AND Discussion}

The ANOVA results of the factors precision; acceptable, multiple and flawed spacing; as well as their interactions are detailed in Table 2.

The coefficient of variation (CV) for the failure in seeding and multiple spacing variables for F1, F2 and F3 factors, are slightly above than those values proposed by Coelho (1996). This author mentioned maximum values of 30\% for the evaluation of pneumatic seed meters. For the horizontal disc meter, values are still in the acceptable range, which is a maximum of $50 \%$ for the multiple and acceptable spacing variables in F1, F2 and F3 factors and failure in seeding for the F2 factor.

Regarding the data analyzed for the accuracy variable, the analyzed results did not exceed the practical limit set by Kachman \& Smith (1995), which is $29 \%$. According to these authors, this variable may be a good tool to evaluate the seeders performance. There was a significant interaction between the seed meter and the conductor tube.

When combined with the horizontal disc (HD), T1, T3 and T6 conductors did not differ at 0.05 probability and provided the best accuracy rates, according to Kachman \& Smith (1995), the lowest values being those employing the best performance efficiency from the seeder. When combined with the pneumatic meter (PM), the same conductors cited for the HD provided the best precision indexes.
Table 2. Average results for variance analysis and the test of accuracy and spacing between corn seeds

\begin{tabular}{|c|c|c|c|c|}
\hline \multirow{2}{*}{ Factors } & \multicolumn{4}{|c|}{ Variable (\%) } \\
\hline & Accuracy & Acceptable & Multiple & Failure \\
\hline \multicolumn{5}{|l|}{ F1 seed meter } \\
\hline Horizontal disc & $21.96 \mathrm{a}$ & $78.24 \mathrm{~b}$ & $9.50 \mathrm{a}$ & $12.24 \mathrm{a}$ \\
\hline Pneumatic meter & $21.59 \mathrm{a}$ & $82.86 \mathrm{a}$ & $9.60 \mathrm{a}$ & $7.52 \mathrm{~b}$ \\
\hline CV (\%) & 24.13 & 10.32 & 47.63 & 54.32 \\
\hline \multicolumn{5}{|l|}{ F2 conductor tube ${ }^{*}$} \\
\hline T1 & $19.52 b$ & $86.64 \mathrm{a}$ & $6.64 \mathrm{~cd}$ & $6.70 \mathrm{c}$ \\
\hline T2 & $24.06 \mathrm{a}$ & $72.04 \mathrm{C}$ & $12.78 \mathrm{ab}$ & $15.17 \mathrm{a}$ \\
\hline T 3 & $18.30 \mathrm{~b}$ & $88.49 \mathrm{a}$ & $4.63 d$ & $6.87 \mathrm{c}$ \\
\hline T 4 & $25.41 \mathrm{a}$ & $70.45 \mathrm{c}$ & $16.39 \mathrm{a}$ & $13.15 \mathrm{ab}$ \\
\hline T 5 & $23.72 \mathrm{a}$ & $79.91 \mathrm{~b}$ & $9.48 b c$ & $10.59 b$ \\
\hline T 6 & $19.64 b$ & $85.79 \mathrm{a}$ & $7.38 \mathrm{~cd}$ & $6.81 \mathrm{c}$ \\
\hline CV $(\%)$ & 10.87 & 6.54 & 43.92 & 38.93 \\
\hline \multicolumn{5}{|l|}{ F3 Density (seeds ha ${ }^{-1}$ ) } \\
\hline 60.000 & 19.54 & 82.80 & 7.76 & 9.43 \\
\hline 70.000 & 20.42 & 83.01 & 7.48 & 9.50 \\
\hline 80.000 & 22.07 & 79.90 & 10.05 & 10.03 \\
\hline 90.000 & 19.64 & 76.51 & 12.91 & 10.56 \\
\hline CV $(\%)$ & 14.18 & 7.74 & 47.28 & 55.54 \\
\hline \multicolumn{5}{|l|}{ F Test } \\
\hline F1 seed meter & $0,23 \mathrm{~ns}$ & $14,81 * *$ & $0,012 \mathrm{~ns}$ & 29,33 ** \\
\hline F2 conductor tube & 50,20 ** & 69,82 ** & $26,60 * *$ & 29,24 ** \\
\hline F3 density (seeds ha ${ }^{-1}$ ) & $29,75--$ & $11,44--$ & $14,93--$ & $0,44--$ \\
\hline F1 X F2 & 12,84 ** & 32,20 ** & 13,98 ** & 10,39 ** \\
\hline F1 XF3 & $2,47 \mathrm{~ns}$ & $1,02 \mathrm{~ns}$ & $0,30 \mathrm{~ns}$ & $0,53 \mathrm{~ns}$ \\
\hline F2 X F3 & $0,61 \mathrm{~ns}$ & 2,35 ** & 2,10 * & $0,74 \mathrm{~ns}$ \\
\hline F1 XF2 XF3 & $0,55 \mathrm{~ns}$ & $1,11 \mathrm{~ns}$ & $0,48 \mathrm{~ns}$ & $1,26 \mathrm{~ns}$ \\
\hline
\end{tabular}

* For details of T1-T6 see Figure 1

-- Treatments are quantitative; The F test does not apply ** Significant at 0.01 probability $(p<$ $0.01)$ *Significant at 0.05 probability $(0.01=<p<0.05)$ ns not significant $(p>=0.05)$

The T2, T4 and T5 conductors demonstrated a reduction in accuracy. The probable factor contributing to this decrease may be related to the conductor tube shape allied to the seeds release form by the metering system. The averages of the interaction between the seed meter disc and the conductor tubes for acceptable, multiple, failure in seeding and accuracy are shown in Table 3.

It was observed that when combined with the HD, all conductor tubes kept an acceptable average above $70 \%$, with 
Table 3. Means of interactions between factors, seed meter mechanisms (factor 1) and conductor tubes (factor 2) for the variables acceptable, multiple and failure in seeding in corn seeds

\begin{tabular}{|c|c|c|c|c|c|c|c|c|}
\hline \multirow{3}{*}{$\begin{array}{l}\text { Conductor } \\
\text { tube }^{\star}\end{array}$} & \multicolumn{2}{|c|}{ Accuracy } & \multicolumn{2}{|c|}{ Acceptable } & \multicolumn{2}{|c|}{ Multiple } & \multicolumn{2}{|c|}{ Failure } \\
\hline & PM & HD & PM & HD & PM & HD & PM & HD \\
\hline & \multicolumn{8}{|c|}{$(\%)$} \\
\hline T1 & 17.44 bC & $21.60 \mathrm{aABC}$ & $93.57 \mathrm{aA}$ & $79.71 \mathrm{bAB}$ & 3.63 bD & $9.65 \mathrm{aA}$ & 2.78 bC & $10.62 \mathrm{aB}$ \\
\hline T2 & $24.32 \mathrm{aB}$ & $23.80 \mathrm{aA}$ & $71.59 \mathrm{aC}$ & $72.50 \mathrm{aC}$ & $14.83 \mathrm{aB}$ & $10.73 \mathrm{bA}$ & $13.57 \mathrm{bA}$ & $16.76 \mathrm{aA}$ \\
\hline T3 & $17.00 \mathrm{bC}$ & $19.60 \mathrm{aC}$ & $94.54 \mathrm{aA}$ & 82.44 bA & 2.04 bD & $7.21 \mathrm{aA}$ & $3.41 \mathrm{bBC}$ & $10.34 \mathrm{aB}$ \\
\hline T4 & $27.01 \mathrm{aA}$ & $23.81 \mathrm{bA}$ & 63.40 bD & $77.50 \mathrm{aABC}$ & $21.64 \mathrm{aA}$ & $11.13 \mathrm{bA}$ & $14.94 \mathrm{aA}$ & $11.36 \mathrm{bB}$ \\
\hline T5 & $25.09 \mathrm{aAB}$ & $22.34 \mathrm{bAB}$ & $83.12 \mathrm{aB}$ & 76.70 bBC & $9.54 \mathrm{aC}$ & $9.43 \mathrm{aA}$ & 7.33 bB & $13.86 \mathrm{aAB}$ \\
\hline T6 & $18.68 \mathrm{aC}$ & $20.60 \mathrm{aBC}$ & $90.96 \mathrm{aA}$ & 80.62 bAB & $5.90 \mathrm{aCD}$ & $8.86 \mathrm{aA}$ & $3.12 \mathrm{bC}$ & $10.51 \mathrm{aB}$ \\
\hline
\end{tabular}

* For details of treatments see Figure 1

Means followed by the same lower case letter in each line and the uppercase letter in each column do not differ at the level of 0.05 probability by the Tukey test; HD - Horizontal Disc; PM - Pneumatic Meter

a variation of approximately $10 \%$ between the highest and the lowest percentage. These results are in agreement with Melo et al. (2013) and Tourino et al. (2009), who state that the seeder with the pneumatic meter tends to present a better performance in the seeds distribution uniformity when compared to the seeder with horizontal disc meter.

The corn seed shape may be the determining factor for reducing the conductor tubes interference. Because these seeds are flat, they undergo a minor rolling action inside the furrow after being released by the conductor tube, even if it is straight, these results differ from the conclusions reached by Kocher et al. (2011), who obtained better results with round seeds.

When combined with the PM, T1, T3 and T6 conductors kept the percentage of acceptable spacing above 90\%. T3 and $\mathrm{T} 6$ conductors have a discharge angle close to $30^{\circ}$. The $\mathrm{T} 1$ conductor has a straight discharge profile and seed input angle around $6^{\circ}$, therefore, after being released by the metering system, the seeds are not slowed in their fall, as stated by (Carpes et al. 2016).

There was no significant difference between the conductor tubes, when combined with the $\mathrm{HD}$, however; $\mathrm{T} 3$ provided the smallest occurrence for multiple spacing. The T4 conductor had the highest average for multiple spacing, the probable factor for the quality reduction being probably the seed inlet angle that can provide a greater intensity of rebounds within the conductor tube, as well as T2, due to its small diameter seed output. These results are in accordance with Pacheco et al. (1996), who comment that there is a greater number of seed rebounds inside due to the small diameter of the conductors, resulting in a higher incidence of multiple spacing. Jasper et al. (2011) concluded that, even occurring a significant reduction of acceptable spacing, when increasing the seeder speed, the pneumatic system showed better results in comparison to the horizontal perforated disc system.

When combined with the PM, T1, T3 and T6 conductors did not differ between them and provided the smallest percentage of multiple spacing. T2 and T4 conductors obtained the highest percentages of multiple spacing, the seeds release format influenced by the PM, possibly due to the seeds acquiring a larger drop rate compared to the HD release, therefore increasing the ricocheting effect inside the conductor.

There was a higher occurrence of failure in seeding when using the horizontal disc meter. Santos et al. (2011) found similar results. T2 and T5 conductors had a smaller discharge diameter, providing the highest percentage of interference.
The conductors with the pneumatic meter (PM) combination reduced the average percentage of fail spacing. The PM's release form may cause the seeds to decrease contact with the tube inner walls, therefore reducing the ricocheting effect and altering the seed spacing. There was a significant interaction between the conductor tubes and the increased seeding density rate for the acceptable spacing variable. The data are shown in Table 4.

In order to obtain higher densities, there is the need to increase the peripheral velocity of the seed meter disc. This increase caused a reduction in acceptable spacing for the tubes used. T1, T3 and T6 conductors did not differ for the four evaluated densities, corroborating with the results obtained by Oliveira et al. (2009), whose tests observed that the distribution uniformity was not significantly affected by the displacement speed. However, T6 obtained the highest numerical reduction for acceptable spacings for the highest seed density used.

The conductors T2, T4 and T6 showed acceptable spacing percentages not linear in intermediate peripheral speeds used in the seed meters, as Reis et al. (2007) observed, who did not obtain linear response in the seeds longitudinal distribution and found the highest acceptable spacing percentages at intermediate speeds among the studied cases. Santos et al. (2011), who claimed that the speed increase in the seeder operation is a factor that interferes with the plant establishment, reducing the number of acceptable spacings between seeds.

The results between the conductor tubes and the seeding density rate interaction for multiple spacing variable is shown in Table 5.

The multiple spacings variable suffered a negative interference with the speed increase, similar results being found by Mahl et al. (2008). With the increase in the seed density rate, and consequently the peripheral speed of the

Table 4. Split averages of conductor tubes (Factor 2) and the seed density (Factor 3) interaction for acceptable spacing variable in corn seeds

\begin{tabular}{|c|c|c|c|c|}
\hline \multirow{2}{*}{$\begin{array}{c}\text { Conductor } \\
\text { tube }^{*}\end{array}$} & \multicolumn{4}{|c|}{ Density (seeds ha-1) } \\
\hline & 60,000 & 70,000 & 80,000 & 90,000 \\
\hline $\mathrm{T} 1$ & $89.31 \mathrm{a}$ & $87.72 \mathrm{a}$ & $88.29 \mathrm{a}$ & $81.25 \mathrm{a}$ \\
\hline $\mathrm{T} 2$ & $71.81 b$ & $74.54 \mathrm{~b}$ & $74.88 \mathrm{c}$ & $66.93 \mathrm{c}$ \\
\hline T3 & $90.22 \mathrm{a}$ & $88.29 \mathrm{a}$ & $88.18 \mathrm{a}$ & $87.27 \mathrm{a}$ \\
\hline T4 & $70.79 b$ & $76.02 \mathrm{~b}$ & $63.97 d$ & $71.02 \mathrm{C}$ \\
\hline T5 & $88.06 \mathrm{a}$ & $81.47 a b$ & $77.84 \mathrm{bc}$ & $72.27 \mathrm{bc}$ \\
\hline T6 & $86.59 \mathrm{a}$ & $90.00 \mathrm{a}$ & $86.25 \mathrm{ab}$ & $80.34 \mathrm{ab}$ \\
\hline
\end{tabular}

* For details of treatments see Figure 1

Means followed by the same lower case letter in each column do not differ at the level of 0.05 probability by the Tukey test 
Table 5. Split means for the conductor tubes (Factor 2) and the seed density (Factor 3) interaction for multiple spacing variable in corn seeds

\begin{tabular}{ccccc}
\hline Conductor & \multicolumn{4}{c}{ Density (seeds ha ${ }^{-1}$ ) } \\
\cline { 2 - 5 } tube $^{*}$ & $\mathbf{6 0 , 0 0 0}$ & $\mathbf{7 0 , 0 0 0}$ & $\mathbf{8 0 , 0 0 0}$ & $\mathbf{9 0 , 0 0 0}$ \\
$\mathrm{T} 1$ & $5.45 \mathrm{bc}$ & $5.45 \mathrm{ab}$ & $5.68 \mathrm{c}$ & $9.99 \mathrm{bc}$ \\
$\mathrm{T} 2$ & $11.47 \mathrm{ab}$ & $10.45 \mathrm{ab}$ & $12.95 \mathrm{~b}$ & $16.25 \mathrm{ab}$ \\
$\mathrm{T} 3$ & $2.61 \mathrm{c}$ & $4.66 \mathrm{bv}$ & $4.77 \mathrm{c}$ & $6.47 \mathrm{c}$ \\
$\mathrm{T} 4$ & $16.59 \mathrm{a}$ & $11.93 \mathrm{a}$ & $21.02 \mathrm{a}$ & $16.02 \mathrm{ab}$ \\
$\mathrm{T} 5$ & $4.54 \mathrm{c}$ & $7.84 \mathrm{ab}$ & $8.86 \mathrm{bc}$ & $16.70 \mathrm{a}$ \\
$\mathrm{T} 6$ & $5.90 \mathrm{bc}$ & $4.54 \mathrm{~b}$ & $7.04 \mathrm{bc}$ & $12.04 \mathrm{abc}$ \\
\hline
\end{tabular}

* For details of treatments see Figure 1

Means followed by the same lower case letter in each column do not differ at the level of 0.05 probability by the Tukey test

seed meter disc, there is an increase in the multiple spacings percentage, specifically for T2, T5 and T6, but it was not linear for $\mathrm{T} 4$ conductor. This effect can be attributed to the variation trend of the seeds, due to the increase in the peripheral speed of the seed meter. Jasper et al. (2011) state that the increase in speed in pneumatic meters can provide an increase in multiple spacing and a reduction in acceptable spacing percentages, also having the contribution by the conductor tube's form, inclination and length.

As for the T6 conductor, the possible factor that increased the number of multiple spacings may be the presence of a seed sensor in the seed path. This can cause a deviation of the seeds normal trajectory, modifying their velocity of fall, generating irregular spacing, being in accordance with Tourino \& Daniel (1998), where the presence of points obstructing the seeds passage, as notches and grooves, should be avoided.

\section{Conclusions}

1. With the increase of peripheral speed of the seed meter disc and, consequently, the increase in the seeding density, there was a tendency towards the reduction of acceptable spacings for most conductors.

2. The conductor tube $\mathrm{T} 3$ with a parabolic profile and exit angle close to 30 degrees, presented the best performance in relation to longitudinal seed distribution, regardless of the type of seed metering disc used.

\section{Literature Cited}

ABNT - Associação Brasileira de Normas Técnicas. Projeto de norma 04: 015.06-004: Semeadora de precisão - ensaio de laboratório método de ensaio. Rio de Janeiro: ABNT, 1994. 7p.

Carpes, D. P.; Alonço, A. dos S.; Francetto, T. R.; Franck, C. J.; Bellé, M. P.; Machado, O. D. da C. Effect of different conductor tubes on the longitudinal distribution of soybean seeds. Australian Journal of Crop Science, v.10, p.1144-1150, 2016. https://doi.org/10.21475/ ajcs.2016.10.08.p7733

Coelho, J. L. D. Ensaio \& certificação das máquinas para a semeadura. In: Mialhe, L. G. (ed.) Máquinas agrícolas: Ensaio \& certificação. Piracicaba: Fundação de Estudos Agrários Luiz de Queiroz, 1996. p.551-569.

Dias, V. de O.; Alonço, A. dos S.; Baumhardt, U. B.; Bonotto, G. J. Distribuição de sementes de milho e soja em função da velocidade e densidade de semeadura. Ciência Rural, v.39, p.1721-1728, 2009. https://doi.org/10.1590/S0103-84782009005000105
Dias, V. de O.; Alonço, A. dos S.; Carpes, D. P.; Veit, A. A.; Souza, L. B. Tamanho amostral para ensaios de mecanismos dosadores de sementes de milho em esteira carpetada. Engenharia Agrícola, v.34, p.1019-1029, 2014. https://doi.org/10.1590/S010069162014000500021

ISO - International Organization for Standardization. ISO 7256/1: Sowing equipment - Methods of test - Part 1: Single seed drills (precision drills). 1984.16p.

Jasper, M.; Assumpção, P. S. M; Rocil, J.; Garcia L. C. Velocidade de semeadura da soja. Engenharia Agrícola, v.31, p.102-110, 2011. https://doi.org/10.1590/S0100-69162011000100010

Jasper, R.; Janszen, U.; Jasper, M.; Garcia, L. C. Distribuição longitudinal e germinação de sementes de milho com emprego de tratamento fitossanitário e grafite. Engenharia Agrícola, v.26, p.292-299, 2006. https://doi.org/10.1590/S0100-69162006000100031

Kachman, S. D.; Smith, J. A. Alternative measures of accuracy in plant spacing for planters using single seed metering. Transactions of the ASAE, v.2, p.379-387, 1995. https://doi.org/10.13031/2013.27843

Kocher, M. F.; Coleman, J. M.; Smith, J. A.; Kachman, S. D. Corn seed spacing uniformity as affected by seed tube condition. American Society of Agricultural and Biological Engineers, v.27, p.177-183, 2011.

Mahl, D.; Furlani, C. E. A.; Gamero, C. A. Efficiency of pneumatic and horizontal perforated disk meter mechanism in corn no-tillage seeders in soil with different mobilization reports. Engenharia Agrícola, v.28, p.535-542, 2008. https://doi.org/10.1590/S010069162008000300014

Melo, R. P.; Albiero, D.; Monteiro, L. A.; Souza, F. H.; Silva, J. G. Qualidade na distribuição de sementes de milho em semeadoras em um solo cearense. Revista Ciência Agronômica, v.44, p.94-101, 2013. https://doi.org/10.1590/S1806-66902013000100012

Mialhe, L. G. Máquinas agrícolas para plantio. 1.ed. Campinas, SP: Millennium, 2012. 623p.

Oliveira, L. G.; Tavares, C. A.; Griggio, A.; Delai, M.; Jung, R.; Bitencourt, R.; Silva, S. L.; Silva, T. R. B. da. Distribuição longitudinal de sementes de milho em função do tipo de dosador de sementes e velocidade de deslocamento. Revista Cultivando o Saber, v.2, p.140-146, 2009.

Pacheco, E. P.; Mantovani, E. C.; Martyn, P. J.; Oliveira, A. C. Avaliação de uma semeadora-adubadora de precisão. Pesquisa Agropecuária Brasileira, v.31, p.209-214, 1996.

Pinheiro Neto, R.; Braccini, A. de L. e; Scapim, C. A.; Bortolotto, V. C.; Pinheiro, A. C. Desempenho de mecanismos dosadores de sementes em diferentes velocidades e condições de cobertura do solo. Acta Scientiarum Agronomy, v.30, p.611-617, 2008. https:// doi.org/10.4025/actasciagron.v30i5.5960

Reis, E. F. dos; Moura, J. R. de; Delmond, J. G.; Cunha, J. P. A. R. da. Características operacionais de uma semeadora-adubadora de plantio direto na cultura da soja (Glycine Max (L.) Merril). Revista Ciências Técnicas Agropecuárias, v.16, p.70-75, 2007.

Santos, A. J. M.; Gamero, C. A.; Oliveira, R. B.; Villen, A. C. Análise espacial da distribuição longitudinal de sementes de milho em uma semeadora-adubadora de precisão. Bioscience Journal, v.27, p.16-23, 2011.

Silva, F. de A. S. e; Azevedo, C. A. V. de. The Assistat Software Version 7.7 and its use in the analysis of experimental data. African Journal of Agricultural Research, v.11, p.3733-3740, 2016. https:/doi. org/10.5897/AJAR2016.11522 
Tourino, M. C. C.; Daniel, L. A. Desenvolvimento e avaliação de um tubo condutor de sementes do tipo trajetória para semeadoras de precisão. Ciência e Agrotecnologia, v.22, p.199-205, 1998.
Tourino, M. C. C.; Rezende, P. M. de; Silva, L. A. da; Almeida, L. G. P. de. Semeadoras-adubadoras em semeadura convencional de soja. Ciência Rural, v.39, p.241-245, 2009. https://doi.org/10.1590/ S0103-84782009000100039 